\title{
Response of Nitrogen on Yield and Seed Quality of Boro Rice
}

\author{
Amina Khatun ${ }^{*}$, M S U Bhuiya ${ }^{2}$ and M A Saleque ${ }^{3}$
}

\begin{abstract}
Nitrogen $(\mathrm{N})$, the most limiting nutrient in Bangladesh, for rice has been studied most rigorously, but its contribution to rice seed production remained relatively unexplored. An experiment was conducted during Boro season (November-April) in 2009-10 at the Bangladesh Rice Research Institute experimental farm, Gazipur, Bangladesh, to evaluate the effect of $\mathrm{N}$ fertilizer on seed yield and its quality. The experiment included BRRI dhan28 and BRRI dhan29 and 0, 50, 100, 150, 200 and $250 \mathrm{~kg} \mathrm{ha}^{-1} \mathrm{~N}$ rates. Seed yield increased significantly in a quadratic fashion with the increase of $\mathrm{N}$ rate both in BRRI dhan 28 and BRRI dhan29. Application of $\mathrm{N}$ fertilizer increased seed yield by about 3-4 tha-1 compared to control. The highest yield of 5.15 and $6.34 \mathrm{t} \mathrm{ha}^{-1}$ was obtained with $150 \mathrm{~kg} \mathrm{~N}^{-1}$ in BRRI dhan 28 and BRRI dhan29 respectively. However, the predicted economic optimum doses of $\mathrm{N}$ appeared as 156 and $158 \mathrm{~kg} \mathrm{ha}^{-1}$ for BRRI dhan28 and BRRI dhan29 respectively. Nitrogen application to rice seed crop did not impair seed quality in terms of germination, viability, vigour and seed color. The seed $\mathrm{N}$ concentration ranged from 0.94 to $1.31 \%$ in BRRI dhan 28 and 0.85 to $1.07 \%$ in BRRI dhan 29 among different $\mathrm{N}$ rates. The seed phosphorus concentration varied from 0.30 to $0.41 \%$ in BRRI dhan 28 and 0.28 to $0.36 \%$ in BRRI dhan 29 among different $\mathrm{N}$ rates. The seed $\mathrm{K}$ varied from 0.23 to $0.27 \%$ and 0.20 to $0.23 \%$ in BRRI dhan 28 and BRRI dhan 29 respectively, among different $\mathrm{N}$ rates. The average seed protein of BRRI dhan28 (6.59\%) was significantly higher than that of BRRI dhan29 $(5.68 \%)$. Seed $\mathrm{N}$ and protein content slightly increased with the increase of $\mathrm{N}$ rate. Nitrogen application did not influence phosphorus and magnesium content in rice seed. However, seed potassium slightly decreased with the $\mathrm{N}$ application.
\end{abstract}

Key words: Rice (Oryza sativa), seed yield, seed quality, nitrogen rate

\section{INTRODUCTION}

Rice (Oryza sativa L.) is the staple food for nearly half of the world's population, mostly live in developing countries. The crop occupies onethird of the world's total area planted to cereals and provides $35-40 \%$ of the calories consumed by 2.7 billion people (Fageria and Baligar, 2001). By 2025, it is estimated that it will be necessary to produce about $60 \%$ more rice than what is currently produced to meet the food needs of a growing world population (Fageria et al., 2003). In order to grow more food from marginal and good quality lands, sustaining the quality of natural base is a concern. Production of quality seed is one of the few means to achieve the goals. Insufficiency of quality seed is one of the rice production constraints for modern rice varieties in Bangladesh. Government and NGO seed supply systems contribute only $15-20 \%$ of total seed demand in the country. Use of quality seed can increase rice yield by $12-15 \%$ at a given management practices (Gomosta, 2004). Several authors reported that rice yield can be increased up to $15-20 \%$ by using quality seed alone (Bhuiyan et al., 2002; Farooq, 2006). In general, rice seed yield is often lower than the grain yield because of seedling mortality, rouging and low nutrient application. Nutrient management strategy in seed crop may be somewhat different from normal grain crop. Only commercial entrepreneurs grow seed crop and price of seed is always several-fold higher than normal food grain price. Seed yield may be increased through proper nutrient management without sacrificing seed quality.

${ }^{1}$ Rice Farming System Division, Bangladesh Rice Research Institute, Gazipur 1701. 2Professor, Agronomy Department, Bangladesh Agricultural University, Mymensingh. ${ }^{3}$ Coordinator for Advanced Studies and Research, Bangladesh Rice Research Institute, Gazipur 1701. *Corresponding author's email: aminabrri@gmail.com 
Nitrogen is one of the most yield-limiting nutrients in rice production around the world, especially in tropical Asian soils and almost every farmer has to apply $\mathrm{N}$ fertilizer to get a desirable yield of rice (Saleque et al., 2004). Judicious use of fertilizers can markedly increase the yield and improve the quality of rice (Chaturvedi, 2005). Given the importance of $\mathrm{N}$ fertilization on the yield in grain, it is necessary to know what the best dose is for each variety as well as its influence on yield components and other agronomic parameters such as plant height, lodging and moisture content of the grain, in order to obtain better knowledge of said productive response (Chaturvedi, 2005). However, both excess and insufficient supply of $\mathrm{N}$ is harmful to the rice crop and may decrease seed yield. An adequate $\mathrm{N}$ supply can increase as much as $60 \%$ rice production over control (Mikkelsen et al., 1995).

Neelam and Chopra (2000) found that the highest plant height, number of panicles $\mathrm{m}^{-2}$, seed weight panicle-1, grain and straw yields were obtained when the $\mathrm{N}$ fertilizer rates increased up to $80 \mathrm{~kg} \mathrm{ha}^{-1}$. However, the seed test showed no effect on seed quality due to $\mathrm{N}$ levels. The proper use of $\mathrm{N}$ fertilizer could improve caryopsis weight of rice by improving the absorbing activity of the root in order to absorb more nutrients from the soil. The increase in amount of $\mathrm{N}$ at the booting stage may provide sufficient $\mathrm{N}$ to rice plants during the late grain filling stage. This could help lessen threats posed by catabolism of structural protein in stem and leaves, thereby extending the life-span of green leaves by maintenance of high photosynthetic rate (Juan et al., 2006). Yoldas et al. (2008) observed that potassium (K), calcium $(\mathrm{Ca})$, magnesium $(\mathrm{Mg})$, iron $(\mathrm{Fe})$, and zinc (Zn) content increased with increases in $\mathrm{N}$ rates but, phosphorus $(\mathrm{P})$, copper $(\mathrm{Cu})$, manganese $(\mathrm{Mn})$, boron $(\mathrm{B})$ and sodium $(\mathrm{Na})$ contents were not influenced. The amino acid contents as well as the nutritional value of protein of plant origin are influenced by the plants species and physiological and agroecological factors. Fertilization, especially $\mathrm{N}$ nutrition, has a very important role on the amino acid contents (Custic et al., 2009). Panicle with a low percentage of sterile flowers permits the application of higher $\mathrm{N}$ doses of and produce better yields (Yoshida, 1981). Increasing rates of $\mathrm{N}$ fertilizer may increase the yield but reduce the quality of the grain (Conry, 1995; Gately and Kelly, 1987).

Excessive dose of $\mathrm{N}$ produces succulent plants and enhances the plants sensitivity to water and temperature stress, susceptible to lodging and pest and disease incidence and in consequence, give poor quality seed of rice (Balasubramaniyan and Palaniappan, 2007). There is an apprehension that the application of nutrient may deteriorate seed quality, although there is little study to develop a nutrient management strategy that combine seed yield increase yet no quality is compensated. Under these circumstances, the present study was undertaken with the objectives to determine the optimum dose of $\mathrm{N}$ on yield and seed quality of Boro rice and seed nutrient composition of rice under varying levels of $\mathrm{N}$ application.

\section{MATERIALS AND METHODS}

A field experiment was conducted during Boro season in 2009-10 at the experimental farm of the Bangladesh Rice Research Institute, Gazipur, Bangladesh $\quad\left(23^{\circ} 59^{\prime} \mathrm{N} \quad\right.$ latitude, $90^{\circ} 24^{\prime} \mathrm{E}$ longitude). The farm belongs to agro-ecological zone (AEZ) number 28 known as Madhupur Tract. The soil of the experimental field is Chhiata clay loam, a member of the fine, hyperthermic Vertic Endoaquept (Saleque et al., 2004). The initial soil chemical properties at $0-15$ $\mathrm{cm}$ soil depth were: $\mathrm{pH}$ 6.1, organic matter $2.02 \%$, total $\mathrm{N}$ content $0.07 \%$, available $\mathrm{P} 10.14$ $\mathrm{mg} \quad \mathrm{kg}^{-1} \quad\left(0.5 \quad \mathrm{M} \quad \mathrm{NaHCO}_{3}\right.$ extracted $)$, exchangeable $\mathrm{K} 0.17 \mathrm{meq} / 100 \mathrm{~g}$ soil (Neutral 1.0 $\mathrm{N} \mathrm{NH}_{4} \mathrm{OAc}$ extracted), available sulfur (S) $20 \mathrm{mg}$ $\mathrm{kg}^{-1}\left[\mathrm{Ca}\left(\mathrm{H}_{2} \mathrm{PO}_{4}\right)_{2}\right.$ extracted], and available $\mathrm{Zn} 2.8$ $\mathrm{mg} \mathrm{kg}^{-1}(0.01 \mathrm{~N} \mathrm{HCl}$ extracted).

The experiment involved two factors, rice variety and $\mathrm{N}$ rate. Two rice varieties, BRRI dhan28 and BRRI dhan29 were grown under irrigated conditions during Boro season. The tested $\mathrm{N}$ rates were $0,50,100,150,200$ and 250 $\mathrm{kg} \mathrm{ha}^{-1}$. Rice was transplanted in the first week of January 2012 with 40-day-old seedlings. Two or three seedlings were transplanted with $20-x$ $20-\mathrm{cm}$ spacing. The experiment was conducted in a randomized complete block design with three replications. Unit plot size was 5- $\times$ 4-m. 
All plots were surrounded by soil levees of 30 $\mathrm{cm}$ high to avoid $\mathrm{N}$ contamination between plots. Nitrogen was applied as urea in three equal splits: 20, 35 and 50 days after transplanting (DAT) for BRRI dhan28 and 20, 35 and 55 DAT for BRRI dhan29. Phosphorus, K, S and $\mathrm{Zn}$ were applied as triple super phosphate, muriate of potash, gypsum and zinc sulphate respectively, during final land preparation. After transplanting, intercultural operations like weeding, irrigation and control of pest were done as and when necessary. At maturity the crop was harvested manually at $15 \mathrm{~cm}$ above ground level. However, 16 hills from each plot were harvested at the ground level for measuring yield components and straw yield. The grain yield was recorded at $12 \%$ moisture content and straw yield as oven dry basis following standard procedures as described by Yoshida et al. (1976). Optimum dose of $\mathrm{N}$ was determined by differentiating the quadratic $\mathrm{N}$ response equation (Colwell, 1994). The grain number panicle- ${ }^{-1}, 1000$-grain weight (TGW) was measured at $12 \%$ moisture and sterility (\%) was calculated following Yoshida et al., 1972. Rice plants from $5 \mathrm{~m}^{2}$ area of the middle of each plot were harvested at above ground level and threshed for grain yield determination.

The quality of the freshly harvested rice seeds were assessed by seed germination, seed viability and seedling vigour test. Seedling vigour was tested following two methods: 1) speed of germination and 2) seedling length measurement (Agrawal, 2005). Germination count was made according to ISTA (2006). The $\mathrm{N}, \mathrm{P}, \mathrm{K}$ and $\mathrm{Mg}$ concentrations in seed grain were determined according to Yoshida et al., 1976. Seed protein content was calculated by multiplying the $\mathrm{N}$ content in seeds by a factor of 5.95 (Juliano, 1972). The seed colour was determined by Munsell Color Chart. Analysis of variance (ANOVA) of the measured parameters was performed and the treatment means were compared using Least Significant Difference (LSD) at the 5\% level of probability (Gomez and Gomez, 1984). The yield trends were analyzed by ordinary least squares linear regression as done by Dawe et al. (2000). The significance test of the regression analysis was done following Statcal (2012).

\section{Khatun et al}

\section{RESULTS AND DISCUSSION Yield contributing characters}

The $\mathrm{N}$ and variety interactions in relation to yield components were not significant $(\mathrm{P}>0.05)$ (Table 1). At N-control treatment, BRRI dhan 28 produced 205 panicle $\mathrm{m}^{-2}$ compared to BRRI dhan29 (167). Receiving $50 \mathrm{~kg} \mathrm{~N} \mathrm{ha}^{-1}$, panicle $\mathrm{m}^{-2}$ in BRRI dhan 28 and BRRI dhan29 was 219 and 220 respectively. Increasing $\mathrm{N}$ rate increased panicle production in both the varieties. At 150 $\mathrm{kg} \mathrm{N}$ ha $^{-1}$, BRRI dhan28 and BRRI dhan29 produced 290 and 268 panicle $\mathrm{m}^{-2}$ which increased to 292 and 288 respectively with 200 $\mathrm{kg} \mathrm{N}$ application. Application of $250 \mathrm{~kg} \mathrm{~N}^{-1}$ increased panicle $\mathrm{m}^{-2}$ abruptly to 314 in BRRI dhan 28 and 338 in BRRI dhan29.

The individual effect of $\mathrm{N}$ for filled grains panicle $^{-1}$ was not significant $(\mathrm{P}>0.05)$. In BRRI dhan28, the higher number of grains panicle ${ }^{-1}$ was observed in $50 \mathrm{~kg} \mathrm{~N}^{-1}$ followed by 100 and $200 \mathrm{~kg} \mathrm{~N} \mathrm{ha}^{-1}$. The number of grains panicle${ }^{1}$ from 150 and $250 \mathrm{~kg} \mathrm{~N}^{-1}$ was statistically similar. The lowest number of grains panicle ${ }^{-1}$ was observed in control-N treatment. In BRRI dhan29, the higher number of grains panicle-1 was obtained from $150 \mathrm{~kg} \mathrm{~N}^{-1}$ followed by 50 $\mathrm{kg} \mathrm{N} \mathrm{ha}{ }^{-1}$ and $200 \mathrm{~kg} \mathrm{~N} \mathrm{ha}^{-1}$. The number of grains panicle-1 from $100 \mathrm{~kg} \mathrm{~N}^{-1} \mathrm{a}^{-1}$ and $250 \mathrm{~kg} \mathrm{~N}$ $\mathrm{ha}^{-1}$ was similar. Varietal difference for grains panicle $^{-1}$ was significant $(\mathrm{P}<0.01) \quad($ Table 1$)$. Irrespective of $\mathrm{N}$ rate, BRRI dhan 29 produced significantly higher number of grains in comparison to BRRI dhan28. The increase in number of grains per panicle was $31 \%$ in BRRI dhan 28 at $50 \mathrm{~kg} \mathrm{~N} \mathrm{ha}^{-1}$ and $24 \%$ in BRRI dhan29 at $150 \mathrm{~kg} \mathrm{~N}$ ha $^{-1}$ compared to control-N treatment.

TGW ranged from 19.4 to $20.4 \mathrm{~g}$ in BRRI dhan 28 and from 18.8 to $19.5 \mathrm{~g}$ in BRRI dhan29, respectively (Table 1). The application of higher doses of $\mathrm{N}$ decreased TGW in both the varieties. BRRI dhan29 had lower TGW than BRRI dhan28 at a given $\mathrm{N}$ dose. BRRI dhan 28 showed TGW of $20.3 \mathrm{~g}$ in N-control plots compared to $19.5 \mathrm{~g}$ in BRRI dhan29. Increasing $\mathrm{N}$ dose up to $200 \mathrm{~kg}$ ha $^{-1}$ had no significant effect on TGW, but the application of $250 \mathrm{~kg} \mathrm{~N}^{-1}$ decreased seed weight significantly in both the varieties.

In BRRI dhan28, the sterility ranged from $22-30 \%$ and it was $17-25 \%$ in BRRI dhan29 (Table 1). Both $\mathrm{N}$ application rates and varieties produced significant effect on the sterility 
percentage. However, interaction effect of $\mathrm{N}$ and variety on sterility percentage was not significant. Irrespective of $\mathrm{N}$ rates, sterility was higher in BRRI dhan28 than BRRI dhan29. In the $\mathrm{N}$-control plots, BRRI dhan 28 and BRRI dhan29 had sterility percentage of 30 and 24 respectively. Receiving $50 \mathrm{~kg} \mathrm{~N}^{\mathrm{Na}}{ }^{-1}$, sterility percentage reduced to 24 and 21 in BRRI dhan 28 and BRRI dhan29 respectively. Increasing the $\mathrm{N}$ rates to $100 \mathrm{~kg} \mathrm{ha}^{-1}$, sterility in BRRI dhan 28 increased to $27 \%$ and in BRRI dhan 29 increased it to $22 \%$. At $150 \mathrm{~kg} \mathrm{~N}^{-1}$, BRRI dhan 28 and BRRI dhan 29 produced 23 and $17 \%$ sterile spikelets respectively. Further increasing the N rates to 200 and $250 \mathrm{~kg} \mathrm{ha}^{-1}$ did not change the sterility percentage in BRRI dhan28, but in BRRI dhan29 it increased. At the highest $\mathrm{N}$ levels, both the varieties had similar sterility percentage. Fageria and Baligar (1999) estimated that the panicle number accounted for $87 \%$ of the variation in yield, while spikelet sterility and TGW accounted for 7 and 3\% yield variation in rice. Zeng and Shannon (2000) observed that filled grain per panicle and sterility percentage accounted for 71.1 and $38.0 \%$ variation respectively, while TGW accounted for only $1.1 \%$ variation in the rice yield. The improved growth attributes, such as plant height and drymatter production, might be responsible for improved yield attributes. It was found that application of $\mathrm{N}$ improves various crop parameters like TGW more productive tillers and thus resulting in higher grain yields (Chaturvedi, 2005).

\begin{tabular}{|c|c|c|c|c|}
\hline $\mathrm{N}$ rate $\left(\mathrm{kg} \mathrm{ha}^{-1}\right)$ & Panicle $\mathrm{m}^{-2}$ & Grains panicle $^{-1}$ & 1000 grain wt (g) & Sterility (\%) \\
\hline \multicolumn{5}{|c|}{ BRRI dhan 28} \\
\hline 0 & 205 & 87 & 20.3 & 30 \\
\hline 50 & 209 & 114 & 20.1 & 22 \\
\hline 100 & 258 & 100 & 20.1 & 27 \\
\hline 150 & 290 & 94 & 20.4 & 23 \\
\hline 200 & 292 & 101 & 19.9 & 24 \\
\hline 250 & 338 & 99 & 19.4 & 24 \\
\hline Avg. & 265 & 99 & 20 & 25 \\
\hline \multicolumn{5}{|c|}{ BRRI dhan 29} \\
\hline 0 & 167 & 107 & 19.5 & 24 \\
\hline 50 & 220 & 119 & 19.4 & 21 \\
\hline 100 & 255 & 111 & 19.3 & 22 \\
\hline 150 & 268 & 133 & 19.3 & 17 \\
\hline 200 & 288 & 118 & 19.2 & 25 \\
\hline 250 & 314 & 116 & 18.8 & 24 \\
\hline Avg. & 252 & 117 & 19 & 22 \\
\hline $\mathrm{LSD}_{0.05}$ for $\mathrm{N}$ & 36.01 & NS & 0.44 & 3.59 \\
\hline $\mathrm{LSD}_{0.05}$ for $\mathrm{V}$ & NS & 9.47 & 0.25 & 2.07 \\
\hline $\mathrm{LSD}_{0.05}$ for $\mathrm{N} \times \mathrm{V}$ & NS & NS & NS & NS \\
\hline CV $(\%)$ & 13.6 & 14.9 & 2.2 & 14.9 \\
\hline
\end{tabular}

NS=not significant at the 0.05 probability levels

\section{Seed yield}

Nitrogen and variety demonstrated significant interaction effect on the seed yield $(\mathrm{P}<0.05)$. Seed yield increased with $\mathrm{N}$ fertilization and showed significant $(\mathrm{P}<0.01)$ quadratic response both in BRRI dhan28 and BRRI dhan29 rice (Fig. 1). The quadratic regression equation $(Y=$ $\left.2881.29+41.23 x-0.13 x^{2}, R^{2}=0.99\right)$ for BRRI dhan 29 and $Y=2606.18+31.72 x-0.10 x^{2}, R^{2}=$ 0.98 ) for BRRI dhan 28 explained $99 \%$ of yield variation in BRRI dhan 29 and $98 \%$ in BRRI dhan 28 by $\mathrm{N}$ application. Varietal effect showed highly significant $(\mathrm{P}<0.01)$ and BRRI dhan29 achieved significantly greater yield compared to
BRRI dhan28 (Fig. 1). BRRI dhan28 and BRRI dhan29 produced 2,486 and 2,908 $\mathrm{kg} \mathrm{ha}^{-1}$ respectively, in the control plots, which increased to 4,130 and 4,534 $\mathrm{kg} \mathrm{ha}^{-1}$ respectively, with $50 \mathrm{~kg} \mathrm{~N}^{-1}$. Increasing $\mathrm{N}$ dose to $100 \mathrm{~kg}$ $\mathrm{ha}^{-1}$, BRRI dhan28 increased yield to $4,864 \mathrm{~kg} \mathrm{ha}^{-}$ 1, while BRRI dhan29 produced 5,186 $\mathrm{kg} \mathrm{ha}^{-1}$. Difference in grain yield between BRRI dhan 28 and BRRI dhan29 was larger at 100 and $150 \mathrm{~kg}$ $\mathrm{N}$ ha-1 compared to other doses. Differentiating the quadratic equation of yield response with respect to applied $\mathrm{N}$ doses, the optimum $\mathrm{N}$ rate was $164 \mathrm{~kg} \mathrm{ha}^{-1}$ both for BRRI dhan28 and BRRI dhan29. However, the economic optimum dose 
was 156 and $158 \mathrm{~kg} \mathrm{ha}^{-1}$ for BRRI dhan 28 and BRRI dhan29 respectively. Singh et al. (1998) also reported that maximum grain yield of 20 lowland rice genotypes was obtained at 150-200 $\mathrm{kg} \mathrm{N} \mathrm{ha-1}$ at IRRI, Philippines. In fertilizer experiments, $90 \%$ of the maximum yield is often considered as an economical rate (Fageria et al., 2003). The $90 \%$ of the maximum grain yield was obtained at $136 \mathrm{~kg} \mathrm{~N} \mathrm{ha}^{-1}$ and $90 \%$ of the maximum shoot dry matter yield was achieved at $120 \mathrm{~kg} \mathrm{~N} \mathrm{ha}^{-1}$ (Fageria et al., 2008). Similarly, Dobermann et al. (2000) obtained maximum average grain yield in the dry season at IRRI, Philippines with 120 to $150 \mathrm{~kg} \mathrm{~N}^{-1}$. Singh et al. (2007) observed $120 \mathrm{~kg} \mathrm{~N} \mathrm{ha}^{-1}$ as an optimum dose for a yield level of 7.45 and $6.80 \mathrm{t} \mathrm{ha}^{-1}$ in Indo-Gangetic plain of Ludhiana, India.

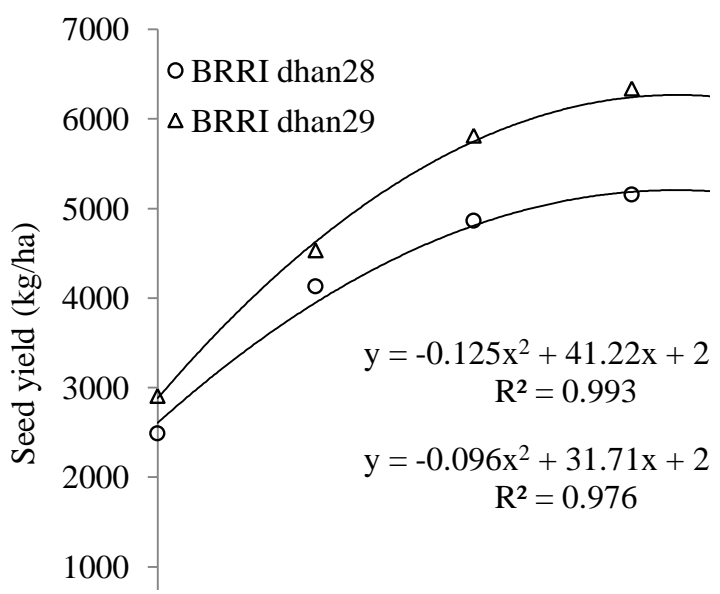

Fig 1. Seed yield of two rice varieties at different rates of nitrogen application.

\section{Seed germination}

Nitrogen and variety interactions on seed germination were insignificant $(p>0.05)$. The individual effect of $\mathrm{N}$ on seed germination was significant $(\mathrm{P}<0.01)$. In BRRI dhan 28 , the $\mathrm{N}$ rate, 50,200 and $250 \mathrm{~kg} \mathrm{ha}^{-1}$ produced the higher germination (\%) followed by control-N treatment (Table 2). The $100 \mathrm{~kg} \mathrm{~N}^{-1}$ produced significantly lower germination in comparison to 50,200 and $250 \mathrm{~kg} \mathrm{~N}^{-1}$.

The lowest germination was obtained from $150 \mathrm{~kg} \mathrm{~N}$ ha- ${ }^{-1}$. The $100 \mathrm{~kg} \mathrm{~N} \mathrm{ha}^{-1}$ and control-N treatment gave statistically similar germination. The 50 and $150 \mathrm{~kg} \mathrm{~N}$ ha $^{-1}$ gave similar germination. The individual effect of variety on seed germination was significant $(\mathrm{P}<0.05)$. Under control-N treatment, BRRI dhan 28 and BRRI dhan29 gave similar germination percentage. At 100 and $150 \mathrm{~kg} \mathrm{~N} \mathrm{ha}^{-1}$, BRRI dhan28 and BRRI dhan29 gave similar germination. A similar scenario was observed at 200 and $250 \mathrm{~kg} \mathrm{~N}^{-1}$. But at $50 \mathrm{~kg} \mathrm{~N}^{-1}$, BRRI dhan28 gave significantly higher germination compared to BRRI dhan29 (Table 2).

\section{Seedling vigour}

Nitrogen and variety interactions demonstrated insignificant effect on seedling vigour. The individual effect of $\mathrm{N}$ on speed of seed germination $(\mathrm{p}<0.05)$ was significant with different levels of $\mathrm{N}$. In BRRI dhan28, the highest speed of germination was obtained from the rate of $200 \mathrm{~kg} \mathrm{~N}^{-1}$ followed by $50 \mathrm{~kg} \mathrm{~N}^{-} \mathrm{a}^{-}$ ${ }^{1}$ and $250 \mathrm{~kg} \mathrm{~N} \mathrm{ha}^{-1}$ (Table 2). The control-N treatment, $100 \mathrm{~kg} \mathrm{~N}^{-1}$ and $150 \mathrm{~kg} \mathrm{~N}^{-1}$ also gave similar speed of germination. The lowest speed of germination was observed in $150 \mathrm{~kg} \mathrm{~N}$ $\mathrm{ha}^{-1}$. In BRRI dhan29, the highest speed of germination was obtained from $250 \mathrm{~kg} \mathrm{~N}$ ha-1 followed by $200 \mathrm{~kg} \mathrm{~N} \mathrm{ha}^{-1}, 100 \mathrm{~kg} \mathrm{~N} \mathrm{ha}^{-1}$ and control-N treatment. The $100 \mathrm{~kg} \mathrm{~N}^{-1}$ and 150 $\mathrm{kg} \mathrm{N}$ ha $^{-1}$ gave similar speed of germination. The lowest speed of germination was observed in $50 \mathrm{~kg} \mathrm{~N} \mathrm{ha}{ }^{-1}$. In BRRI dhan28, $50 \mathrm{~kg} \mathrm{~N}^{-1}$ performed better speed of germination along with $200 \mathrm{~kg} \mathrm{~N}^{-1}$ and $250 \mathrm{~kg} \mathrm{~N}$ ha-1 whereas in BRRI dhan29, it gave reverse performance. The individual effect of $\mathrm{N}$ on vigour index showed insignificant effect with different levels of $\mathrm{N}$ (Table 2). The individual effect of variety on speed of germination $(\mathrm{p}<0.05)$ was significant. At $0,100,150$ and $250 \mathrm{~kg} \mathrm{~N} \mathrm{ha}^{-1}$, BRRI dhan28 
and BRRI dhan29 gave similar speed of germination. At 50 and $200 \mathrm{~kg} \mathrm{~N}$ ha $^{-1}$, BRRI dhan28 gave significantly higher speed of germination in comparison to BRRI dhan29. The individual effect of variety on vigour index $(\mathrm{p}<0.01)$ was also significant. BRRI dhan 28 gave significantly higher vigour index in comparison to BRRI dhan29 at all $\mathrm{N}$ rates (Table 2). These results are partially in agreement with the findings of Khan et al. (2002). They reported that germination percentages, vigour index and growth characters did not vary due to $\mathrm{N}$ application. Vigour testing is important because it often gives a better prediction of field performance and is a more sensitive indicator of seed quality than the standard germination test (Younis et al., 1990). The highest vigour status occurs at physiological maturity after which deterioration processes begin. Deterioration involves loss of membrane integrity, slower respiration, and more leakage of electrolytes and decreased enzyme activity, all of which may be reflected in lower germination percentage.

Table 2. Effect of different nitrogen rates on seed quality of BRRI dhan28 and BRRI dhan29

\begin{tabular}{|c|c|c|c|}
\hline $\begin{array}{l}\text { N rate } \\
\left(\mathrm{kg} \mathrm{ha}^{-1}\right)\end{array}$ & $\begin{array}{c}\text { Germination } \\
(\%)\end{array}$ & Speed of germination & Vigour index \\
\hline \multicolumn{4}{|c|}{ BRRI dhan 28} \\
\hline 0 & 98 & 18.89 & 824.14 \\
\hline 50 & 99 & 19.25 & 854.07 \\
\hline 100 & 96 & 18.76 & 789.88 \\
\hline 150 & 93 & 18.17 & 892.3 \\
\hline 200 & 99 & 19.26 & 875.94 \\
\hline 250 & 99 & 19.12 & 809.11 \\
\hline Avg. & 97 & 18.91 & 840.91 \\
\hline \multicolumn{4}{|c|}{ BRRI dhan 29} \\
\hline 0 & 97 & 18.81 & 644.81 \\
\hline 50 & 92 & 17.72 & 711.15 \\
\hline 100 & 95 & 18.52 & 692.86 \\
\hline 150 & 93 & 18.13 & 551.63 \\
\hline 200 & 98 & 18.81 & 717.23 \\
\hline 250 & 98 & 19.04 & 744.53 \\
\hline Avg. & 96 & 18.51 & 677.04 \\
\hline $\mathrm{LSD}_{0.05}$ for $\mathrm{N}$ & 2.83 & 0.59 & NS \\
\hline $\mathrm{LSD}_{0.05}$ for $\mathrm{V}$ & 1.64 & 0.34 & 63.36 \\
\hline LSD $_{0.05}$ for & NS & NS & NS \\
\hline \multicolumn{4}{|l|}{$\mathrm{N} \times \mathrm{V}$} \\
\hline $\mathrm{CV}(\%)$ & 4.2 & 4.5 & 20.6 \\
\hline
\end{tabular}

NS=not significant at the 0.05 probability levels.

\section{Seed colour}

Different rates of $\mathrm{N}$ did not affect seed colours according to Munsell colour chart. The seed colour was 10YR with value 7 and chroma 6-8.

\section{Seed nutrient content}

The $\mathrm{N}$ and variety interactions in relation to seed $\mathrm{N}$ concentration were not significant $(\mathrm{P}>0.05)$. The individual effect of $\mathrm{N}$ in relation to seed $\mathrm{N}$ concentration was highly significant $(\mathrm{P}<0.01)$ (Table 3). In BRRI dhan28, the seed $\mathrm{N}$ concentration varied from 0.94 to $1.31 \%$ among different $\mathrm{N}$ rates. The highest seed $\mathrm{N}$ content was obtained from $250 \mathrm{~kg} \mathrm{~N}$ ha-1 followed by $200 \mathrm{~kg} \mathrm{~N} \mathrm{ha}{ }^{-1}$ application. The seed N content with the rate of $150 \mathrm{~kg} \mathrm{~N}^{-1}$ was observed significantly lower in comparison to $200 \mathrm{~kg} \mathrm{~N}$ $\mathrm{ha}^{-1}$ and $250 \mathrm{~kg} \mathrm{~N}^{-1}$. Application of $\mathrm{N}$ at 100 and $150 \mathrm{~kg}^{-1}$ performed similar seed $\mathrm{N}$ concentration. The seed $\mathrm{N}$ content with the application of $100 \mathrm{~kg} \mathrm{~N} \mathrm{ha-1}$ performed significantly higher in comparison to the application $50 \mathrm{~kg} \mathrm{~N} \mathrm{ha-1}$. The lowest seed $\mathrm{N}$ concentration $(0.94 \%)$ was observed in control$\mathrm{N}$ plots. The seed $\mathrm{N}$ content from control-N and $50 \mathrm{~kg} \mathrm{~N}$ ha $^{-1}$ performed similar concentration. However, with the increase of $\mathrm{N}$ rate increased seed $\mathrm{N}$ concentration progressively. In BRRI dhan29, the seed $\mathrm{N}$ concentration varied from 0.85 to $1.07 \%$ among different $\mathrm{N}$ rates. The higher seed $\mathrm{N}$ content was obtained from the rate of $200 \mathrm{~kg} \mathrm{~N}^{-1}$ and $250 \mathrm{~kg} \mathrm{~N} \mathrm{ha}^{-1}(1.07 \%)$. The seed $\mathrm{N}$ content with $150 \mathrm{~kg} \mathrm{~N}$ ha $^{-1}$ performed significantly lower in comparison to $200 \mathrm{~kg} \mathrm{~N}$ ha-1. The seed N content with $100 \mathrm{~kg}$

29 Khatun et al 
$\mathrm{N}$ ha $^{-1}$ and $150 \mathrm{~kg} \mathrm{~N}$ ha-1 gave similar concentration. Application of $100 \mathrm{~kg} \mathrm{~N} \mathrm{ha-1}$ produced significantly higher seed $\mathrm{N}$ concentration in comparison to the application of $50 \mathrm{~kg} \mathrm{~N} \mathrm{ha-1}$. The lowest seed $\mathrm{N}$ content was observed in control-N plots. However, this value was similar to $50 \mathrm{~kg} \mathrm{~N} \mathrm{ha-1}$. The application of $\mathrm{N}$ in BRRI dhan29 increased seed $\mathrm{N}$ concentration progressively similar to that obtained in BRRI dhan28. The individual effect of variety on seed $\mathrm{N}$ concentration was highly significant $(\mathrm{P}<0.01)$. Average over the $\mathrm{N}$ doses, including control, BRRI dhan28 produced significantly higher seed $\mathrm{N}$ concentration (1.11\%) compared to BRRI dhan29 (0.95\%). The $\mathrm{N}$ and variety interactions and the individual effects of $\mathrm{N}$ and variety in relation to seed $\mathrm{P}$ concentrations were insignificant $(\mathrm{P}>0.05)$ (Table 3). The individual effect of variety in relation to seed $\mathrm{P}$ concentration was insignificant $(\mathrm{P}>0.05)$. BRRI dhan 28 and BRRI dhan29 produced similar seed $\mathrm{P}$ concentration. The effects of $\mathrm{N}$ rate in relation to seed $\mathrm{K}$ concentration was highly significant $(\mathrm{P}<0.01)$. In BRRI dhan28, the seed $\mathrm{K}$ varied from 0.23 to $0.27 \%$ among different $\mathrm{N}$ rates. The higher seed $\mathrm{K}(0.27 \%)$ was obtained from control-N rates and $50 \mathrm{~kg} \mathrm{~N}^{-1}$ rates followed by the $100 \mathrm{~kg} \mathrm{~N}$ $\mathrm{ha}^{-1}(0.26 \%)$. The seed $\mathrm{K}$ concentration from the rate of $100 \mathrm{~kg} \mathrm{~N} \mathrm{ha}^{-1}, 150 \mathrm{~kg} \mathrm{~N} \mathrm{ha}^{-1}$ and $200 \mathrm{~kg} \mathrm{~N}$ ha $^{-1}$ was similar (Table 3 ). The lowest seed $\mathrm{K}$ was observed in $250 \mathrm{~kg} \mathrm{~N} \mathrm{ha-1} \mathrm{(0.23 \% ).}$ However, the $\mathrm{K}$ concentration declined gradually with the increase of $\mathrm{N}$ rates and apparently it was the reverse scenario of seed $\mathrm{N}$ concentration. The $\mathrm{N} \times \mathrm{V}$ interactions and the individual effect of $\mathrm{N}$ in relation to seed $\mathrm{Mg}$ concentration were not significant $(\mathrm{P}>0.05)$. The individual effect of variety in relation to seed $\mathrm{Mg}$ concentration was significant $(\mathrm{P}<0.05)$. BRRI dhan28 produced significantly higher seed $\mathrm{Mg}$ $\%$ compared to BRRI dhan29 irrespective of $\mathrm{N}$ rate (Table 3 ). The $\mathrm{N}$ and variety interactions in relation to seed protein content were insignificant $(\mathrm{P}>0.05)$. But the main effect of $\mathrm{N}$ rate in relation to seed protein content was highly significant $(\mathrm{P}<0.01)$. The seed protein $\%$ varied from 5.62 to $7.77 \%$ among different $\mathrm{N}$ rates. The highest seed protein $(7.77 \%)$ was obtained from $250 \mathrm{~kg} \mathrm{~N}^{-1}$ followed by $200 \mathrm{~kg}$ $\mathrm{N} \mathrm{ha}^{-1}(7.71 \%)$. With the application of $150 \mathrm{~kg} \mathrm{~N}$ ha $^{-1}$, the seed protein content was observed significantly lower in comparison to the rate of $200 \mathrm{~kg} \mathrm{~N} \mathrm{ha}^{-1}$ (7.71\%) and $250 \mathrm{~kg} \mathrm{~N} \mathrm{ha}^{-1}$ (7.77\%). The seed protein content had similar concentration with the application $100 \mathrm{~kg} \mathrm{~N} \mathrm{ha}^{-1}$ and $150 \mathrm{~kg} \mathrm{~N} \mathrm{ha}^{-1}$. But seed protein at $100 \mathrm{~kg} \mathrm{~N}$ ha $^{-1}$ was significantly higher (6.20\%) incomparison to $50 \mathrm{~kg} \mathrm{~N}$ ha $^{-1}(5.70 \%)$. The lowest seed protein (5.62\%) was observed in the control-N plots. However, with the application of $50 \mathrm{~kg} \mathrm{~N} \mathrm{ha}^{-1}$ and control-N plots performed similar seed protein concentration. It was observed that increasing $\mathrm{N}$ rates increased seed protein concentration progressively (Table 3). The seed protein in rice grain with the application of $150 \mathrm{~kg} \mathrm{~N}$ ha-1 was significantly lower compared to $200 \mathrm{~kg} \mathrm{~N} \mathrm{ha}^{-1}$. Application of $100 \mathrm{~kg} \mathrm{~N} \mathrm{ha-1}$ and $150 \mathrm{~kg} \mathrm{~N}$ ha-1 produced similar seed protein. On the other hand, application of $100 \mathrm{~kg} \mathrm{~N}$ ha-1 gave significantly higher seed protein compared to $50 \mathrm{~kg} \mathrm{~N}$ ha-1. The lowest seed protein was obtained from control-N plots $(5.07 \%)$, however, this value was similar to application of $50 \mathrm{~kg} \mathrm{~N} \mathrm{ha-1.} \mathrm{The}$ individual effect of variety in relation to seed protein was highly significant $(\mathrm{P}<0.01)$. The average seed protein of BRRI dhan28 (6.59\%) was significantly higher in comparison to BRRI dhan29 (5.68\%) irrespective of $\mathrm{N}$ rate (Table 3). Hossain et al. (2009) reported fertilizers had significant influence on protein percentage in brown rice of BRRI dhan28. They obtained the highest protein $(7.78 \%)$ in rice with the recommended chemical fertilizer (NPKSZn) dose and the lowest (6.80\%) was in the control. Blunenthal et al. (2008) observed that $\mathrm{N}$ often affects amino acid composition of protein and in turn its nutritional quality in rice crop. Uppal and Bali (1997) reported that protein content increased significantly with the increased dose of nitrogen in rice. Sikdar et al. (2008) reported significant varietal difference in $\mathrm{N}$ content, $\mathrm{N}$ uptake, protein and aroma of rice grain. Varietal differences in rice on $\mathrm{N}$ content and consequently protein percentage have been reported frequently (Mannan 2005; Saleque et al., 2005). Total soluble protein of freshly harvested rice seed influenced significantly by planting time, $\mathrm{N}$ level and mode of $\mathrm{N}$ application. Total soluble protein ranged from 5.12 to $9.27 \mathrm{mg} \mathrm{g}^{-1}$ which is in agreement with the findings of Sinclair and De Wit (1975) who found 8 to $16 \%$ proteins in cereal seed. 
Bangladesh Rice J. 18(1\&2): 24-32, 2014

Table 3. Nutrient contents of seeds of two rice varieties

\begin{tabular}{|c|c|c|c|c|c|}
\hline $\begin{array}{l}\text { N rate } \\
\left(\mathrm{kg} \mathrm{ha}^{-1}\right)\end{array}$ & $\mathrm{N} \%$ & $\mathrm{P} \%$ & $\mathrm{~K} \%$ & $\mathrm{Mg} \%$ & Protein $\%$ \\
\hline \multicolumn{6}{|c|}{ BRRI dhan 28} \\
\hline 0 & 0.94 & 0.34 & 0.27 & 0.087 & 5.62 \\
\hline 50 & 0.96 & 0.41 & 0.27 & 0.088 & 5.70 \\
\hline 100 & 1.04 & 0.33 & 0.26 & 0.088 & 6.20 \\
\hline 150 & 1.10 & 0.36 & 0.25 & 0.088 & 6.55 \\
\hline 200 & 1.30 & 0.30 & 0.24 & 0.090 & 7.71 \\
\hline 250 & 1.31 & 0.31 & 0.23 & 0.087 & 7.77 \\
\hline Avg. & 1.11 & 0.34 & 0.25 & 0.088 & 6.59 \\
\hline \multicolumn{6}{|c|}{ BRRI dhan 29} \\
\hline 0 & 0.85 & 0.32 & 0.23 & 0.087 & 5.07 \\
\hline 50 & 0.87 & 0.33 & 0.23 & 0.085 & 5.20 \\
\hline 100 & 0.96 & 0.36 & 0.22 & 0.086 & 5.70 \\
\hline 150 & 0.90 & 0.30 & 0.22 & 0.087 & 5.38 \\
\hline 200 & 1.07 & 0.28 & 0.20 & 0.085 & 6.36 \\
\hline 250 & 1.07 & 0.30 & 0.19 & 0.087 & 6.38 \\
\hline Avg. & 0.95 & 0.32 & 0.22 & 0.086 & 5.68 \\
\hline $\mathrm{LSD}_{0.05}$ for $\mathrm{N}$ & 0.07 & NS & 0.02 & NS & 0.42 \\
\hline $\mathrm{LSD}_{0.05}$ for $\mathrm{V}$ & 0.04 & NS & 0.01 & 0.002 & 0.24 \\
\hline \multicolumn{6}{|l|}{$\mathrm{LSD}_{0.05}$ for } \\
\hline $\mathrm{N} \times \mathrm{V}$ & NS & NS & NS & NS & NS \\
\hline CV (\%) & 6.70 & 17 & 7.20 & 3.10 & 6.70 \\
\hline
\end{tabular}

$\mathrm{NS}=$ not significant at the 0.05 probability levels.

\section{CONCLUSIONS}

BRRI dhan29 produced about $1 \mathrm{t}$ ha-1 more seed than the BRRI dhan28, the $\mathrm{N}$ requirement for both the varieties was $164 \mathrm{~kg} \mathrm{ha}^{-1}$. Nitrogen application to rice seed crop did not impair seed quality in terms of germination, viability, vigour and seed colour. However, a slight difference in $\mathrm{N}, \mathrm{P}, \mathrm{K}$ and $\mathrm{Mg}$ contents due to $\mathrm{N}$ management resulted in little variation in the seed qualities of the tested varieties. Popular belief in the deterioration of seed quality due to the application of chemical fertilizer seems to have little acceptability.

\section{REFERENCES}

Agrawal, R L. 2005. Seed Technology. Oxford \& IBH Publishing Co. Pvt. Ltd., New Delhi, India. pp. 565-590.

Balasubramaniyan, P and S P Palaniappan. 2007. Principles and Practices of Agronomy. pp. 185-186. Agrobios (India), Agro house, Chopasani road, Jodhpur 342 002, India.

Bhuiyan, N I, D N R Paul and M A Jabber. 2002. Feeding the extra millions by 2025: Challenges for rice research and extension in Bangladesh. PP. 1-24. Proceedings of the workshop on modern rice cultivation in Bangladesh. Jointly organized by Bangladesh Rice Research Institute (BRRI) and Department of Agricultural Extension (DAE), held at BRRI, Bangladesh on 29-31 January 2002.

Blumenthal, J, D Baltensperger, K G Cassman, S Mason and A Pavlista. 2008. Importance and effect of nitrogen on crop quaslity and health. Agronomy and Horticulture

31 Khatun et al
Department. Agronomy-Faculty Publications. University of Nebraska-Lincoln.

Chaturvedi, I. 2005. Effect of nitrogen fertilizers on growth, yield and quality of hybrid rice. J Central European Agric 6: 611-618.

Colwell, J D. 1994. Estimating fertilizer requirements: A quantitative approach. CAB International, Wallingford, Oxon OX 10SDE, UK.

Conry, M J. 1995. Comparisons of early, normal and late sowing at three rates of nitrogen on the yield, grain nitrogen and screening content of Blenheim spring malting barley in Ireland. J Agril Sci 125: 183-188.

Custic, M H, M Horvatic and M Pecina. 2009. Nitrogen fertilization influences protein nutritional quality in Red Head Chicory. J Plant Nutr 32: 598-609.

Dawe, D, A Dobermann, P Moya, S Abulrachmann, B Singh, P Lal, S Y Li, B Lin, G M Panaullah, O Sariam, Y Singh, A Swarup, P S Tan and Q X Zhen. 2000. How widespread are yield declines in long-term rice experiments in Asia? Field Crops Res 66: 175-193.

Dobermann, A, D Dawe, R P Roetter and K G Cassman. 2000. Reversal of rice yields decline in a long term continuous cropping experiment. Agron J 92: 633-643.

Fageria, N K and M P Barbosa Filho. 2001. Nitrogen use efficiency in lowland rice genotypes. Commun Soil Sci Plant Ana 32: 2079-2089.

Fageria, N K and V C Baligar. 1999. Yield and yield components of lowland rice as influenced by timing of nitrogen fertilization. J Plant Nutr 22: 23-32.

Fageria, N K and V C Baligar. 2001. Lowland rice response to nitrogen fertilization. Commun Soil Sci Plant Ana 32: 1405-1429.

Fageria, N K and V C Baligar. 2005. Enhancing nitrogenuse efficiency in crop plants. Adv Agron 88: 97-185.

Fageria, N K, A B Santos and V A Cutrim. 2008. Dry matter and yield of lowland rice genotypes as influenced by nitrogen fertilization. J Plant Nutr 31: 788-795.

Fageria, N K, M P Barbosa Filho, L F Stone and C M Guimaraes. 2004. Phosphorus nutrition of upland rice. 
P. 401-418. In: T. Yamada and S R S. Abdalla (eds)., Phosphorus in Brazilian Agriculture. Piracicaba, Sao Paulo, Brazil: Brazilian Potassium and Phosphate Institute.

Fageria, N K, N A Stalon and V C Baligar. 2003. Nutrient management for improving lowland rice produc-tivity and sustainability. Adv Agron 80: 63-152.

Farooq, A. 2006. Demand and supply of different crop seeds: Perspective (2005-2011). Proceedings of the workshop on National seed conference and Fair 2006. Organized by Ministry of Agriculture, held at Bangladesh-China Friendship conference centre on 5-7 September 2006.

Gately, T F and D Kelly. 1987. Sources of nitrogen for spring barley. Soils and Grassland Production Research Report. pp. 27-28. Dublin. An Foras Taluntais.

Gomez, K A and A A Gomez. 1984. Statistical procedure for agricultural research (2nd ed.). John Willey and Sons, Singapore. pp. 28-192.

Gomosta, A R. 2004. Emerging technologies for sustainable rice production in Bangladesh. Keynote presented in the 20th HYV workshop, 15-17 March 2004, BRRI, Gazipur.

Hossain, M F, M S U Bhuiya, M Ahmed and M H Mian. 2009. Effect of organic and inorganic fertilizer on the milling and physicochemical properties of aromatic rice. Thai J Agril Sci 42: 213-218.

ISTA (International Seed Testing Association). 2006. International rules for seed testing. International Seed Testing Association, Bassersdorf, Switzerland.

Juan, C, W Zhong, C Gang and M Yi-wei. 2006. Effects of nitrogen fertilizer treatments on filling and respiratory rate of caryopsis in rice. Rice Sci 13: 199-204

Juliano, B O. 1972. Physicochemical properties of starch and protein in relation to grain quality and nutritional value of rice. In: International Rice Res Institute, Rice Breeding, pp. 389-405.

Khan, M A I, M S Hossain, M A Rahman, S M J Hossain and G M M Rahman. 2002. Solar heat: It's use for controlling seed borne fungal infections of wheat. Pakistan J Bio Sci 5: 449-451.

Kiniry, J R, G McCauley, Y Xie and J G Arnold. 2001. Rice parameters describing crop performance of four U. S. cultivars. Agron J 93: 1354 -1361.

Mannan, M A. 2005. Effect of planting date, nitrogen fertilization and water stress on growth, yield and quality of fine rice. PhD Thesis. Dept. Agron. Bangladesh Agril. Univ. Mymensingh, Bangladesh. pp. 94-111.

Mikkelsen, D S, G R Jayaweera and D E Rolston. 1995. Nitrogen fertilizer practices of lowland rice culture. In: Nitrogen fertilization and the environment. pp. 171223.

Neelam, K C and N Chopra. 2000. Effect of row spacing and nitrogen level on growth, yield and seed quality of rice (Oryza sativa) under transplanted conditions. Indian J Agron 45: 304-308.

Saleque, M A, M J Abedin, N I Bhuiyan, S K Zaman and G M Panaullah. 2004. Long-term effects of inorganic and organic fertilizer sources on yield and nutrient accumulation of lowland rice. Field Crops Res 86: 5365.

Saleque, M A, U A Naher, N N Choudhury and A T M S Hossain. 2005. Variety-specific nitrogen fertilizer recommendation for lowland rice. Commun Soil Sci Plant Ana 35: 1891-1903.
Sikdar, M S I, M M Rahman, M S Islam, M S Yeasmin and M M Akhter. 2008. Effect of nitrogen level on aromatic rice varieties and soil fertility status. Int J Sustain Crop Prod 3: 49-54.

Sinclair, T R and C T De Wit. 1975. Photosynthate and nitrogen requirements for food production by various crops. Sci 189: 565-567.

Singh, U, J K Ladha, E G Castillo, G Punjalan, A Tirol-Padre and M Duqueza. 1998. Genotypic variation in nitrogen use efficiency in medium and long duration rice. Field Crops Res 58: 35-53.

Singh, Y, R K Gupta, B Singh and S Gupta. 2007. Efficient management of fertilizer nitrogen in wet direct-seeded rice (Ovza sativa) in northwest India. Indian J Agril Sci 77: 561- 564 .

Statcal.

http://www.danielsoper.com/statcalc3/calc.aspx?id= 15

Uppal, H S and A S Bali. 1997. Quality of Basmoti rice kernel in relation to irrigation and planting dates. J Res Panjab Agril Univ 34: 251-258.

Yoldas, F, S Ceylan, B Yagmur and N Mordogan. 2008. Effects of nitrogen fertilizer on yield quality and nutrient content in broccoli. J Plant Nutr 31: 1333-1343.

Yoshida, S. 1981. Fundamentals of rice crop science. IRRI, Los Banos. Philippines. pp. 235-237.

Yoshida, S, D A Forno, J H Cock and K A Gomez. 1976. Laboratory Manual for Physiological Studies of Rice. 3rd ed. International Rice Research Institute, Manila, Philippines.

Yoshida, S, J H Cock and F T Parao. 1972. Physiological aspects of high yield. Int Rice Res Inst, Rice breeding. pp 455-469.

Younis, S A, F I Al-Rawi and E G Hagor. 1990. Physiological and biochemical parameters of seed quality in some rice varieties (Oryza sativa L.). Seed Res 18: 148-153.

Zeng, L and M S Shannon. 2000. Salinity effects on seedling growth and yield components of rice. Crop Sci 40: 9961003. 